\title{
Division Size and Shade Density Influence Growth and Container Production of Hakonechloa macra Makino 'Aureola'
}

\author{
Michael P. Harvey ${ }^{1}$ and Mark H. Brand ${ }^{2}$ \\ Department of Plant Science, U-4067, University of Connecticut, Storrs \\ CT 06269-4067
}

Additional index words. nursery production, ornamental grasses, production efficiency, propagation

\begin{abstract}
Hakonechloa macra Makino 'Aureola' is an ornamental, shade tolerant landscape grass that grows slowly and commands high prices. Hakonechloa plants grown from four initial division sizes, of 1-2, 4-6, 8-10, or 12-15 tiller buds, were evaluated following a complete growing season (105 days). Based on visual observation, we rated $100 \%$ of plants grown from the two larger division sizes to be salable compared with only 30\% of those from divisions containing 4-6 growing points, and none from the smallest division size. However, divisions of 1-2 tiller buds produced twice as many new shoots and tiller buds per initial tiller bud as did larger division sizes. To produce salable plants in one growing season, results suggest the use of 8-10 tiller bud divisions, but for propagation and increase of stock material, where it is important to obtain the greatest number of new growing points per initial growing point, use of the smaller division sizes is indicated. Hakonechloa plants were grown under shading densities of $0 \%, 30 \%, 50 \%$, or $70 \%$ provided by polypropylene shade cloth. Shading increased overall growth and improved the appearance and leaf color of Hakonechloa, but at $70 \%$ shade density, plants appeared languid and open. For this reason, $\mathbf{5 0 \%}$ shading is recommended for nursery production of Hakonechloa macra 'Aureola'.
\end{abstract}

Ornamental grasses are generally easy to grow, adaptable to an array of soil, temperature, and moisture conditions, and virtually pest and disease free (Darke, 1994). This versatile group of plants can be used in many garden situations because of the numerous species and cultivars that exist, which vary in foliage color, height, shape, and texture. Due to increased concerns over conservation and environmental quality, perennial grasses have been applauded for their low maintenance needs (Corley, 1989). Greater emphasis on the use of ornamental grasses in the landscape has significantly increased sales of these perennials (LavisHam, 1993). Despite this popularity, knowledge regarding their cultural requirements, hardiness and growth rates is lacking, thus preventing growers from producing and marketing grasses as effectively as other groups of plants (Brand, 1999). This limited understanding is partly due to the lack of scientific investigation into ornamental grass growth and production.

Received for publication 12 Nov. 2000. Accepted for publication 8 May 2001. Storrs Agricultural Experiment Station scientific contribution 2004. This research was conducted with Hatch funds and a grant from New England Grows. This paper is part of a thesis submitted in partial fulfillment of the requirements for the MS degree.

${ }^{1}$ Graduate Research Assistant, currently Director at the Bartlett Arboretum, 151 Brookdale Rd., Stamford, CT 06903-4199.

${ }^{2}$ Associate Professor.
A majority of cultivated ornamental grasses must be vegetatively propagated to maintain a desirable phenotype. Division has been the standard method of propagation (Brand, 1999; Corley, 1989). Propagation from cuttings is an additional asexual technique that can be used on some species or cultivars, including Chasmanthium latifolium Michx., Elymus arenarius L. 'Glauca', Panicum virgatum L. 'Heavy Metal', Imperata cylindrica L. 'Red Baron', Sorghastrum nutans L., Pennisetum setaceum (Forssk.) Chiov. 'Rubrum', and Phalaris arundinaceae L. 'Picta' (Barnes, 1994; Corley, 1989). Production of some ornamental grasses by division is relatively slow, especially for the variegated types (Ruffino, Sebastian, personal communication). Despite this, variegated grasses are frequently the most popular cultivars and comprise $25 \%$ and $30 \%$ of commercial sales (Pennisi and McConnell, 2000). Our research focused on enhancing the nursery production of the variegated grass Hakonechloa macra Makino 'Aureola' because of its slow growth, popularity for landscaping and high market value.

In many nursery operations, ornamental grasses are normally potted in May from plugs or liners grown from divisions of the previous season's container crop. Division size is not a critical a factor in propagation of vigorous ornamental grass species, such as Pennisetum and Panicum, where plants can yield a large number of liners (Brand, 1999). When propagating a slow-growing ornamen- tal grass for which stock supply is limited, using the smallest possible division is necessary to produce significant quantities of liners. In this experiment, we examined the growth of Hakonechloa macra 'Aureola' resulting from a range of initial division sizes to determine which size is most economical for liner propagation and nursery production.

A shade tolerance study of six ornamental grasses found that while plant height was unaffected by shade intensity, the effect of shade on plant width varied by grass species and year (Cole and Cole, 2000). Hakonechloa macra 'Aureola' is a cultivar of a species which grows naturally on the slopes of cool, mesic, forested mountains in Japan (Watson and Dallwitz, 1992), and is considered shade tolerant by horticulturists (Greenlee, 1992). An informal Univ. of Connecticut telephone survey of 10 northern United States ornamental grass producers revealed that the density of shade used during Hakonechloa production varied from $0 \%$ to $70 \%$. In a second experiment, plants were grown under a range of shade cloth densities to determine which amount of shading is most beneficial for Hakonechloa production.

\section{Materials and Methods}

Source of plants. Stock plants used for the division study and to generate liners for the shade study were obtained as uniform, 2.6-L container-grown plants from two commercial nurseries. The dormant plants were held in a cold frame until needed for experimentation.

Division study. The influence of division size on Hakonechloa macra 'Aureola' production was evaluated by making a series of graded divisions differing in the number of tiller buds. Dormant, container-grown stock plants were divided into $1-2,4-6,8-10$, or 12-15 tiller bud divisions during the first 2 weeks of April. Divisions were grown in 325 mL containers with a 3 pinebark : 2 sphagnum peatmoss : 1 sand (by volume) potting mixture amended with dolomitic limestone at $5.75 \mathrm{~kg} \cdot \mathrm{m}^{-3}$. To facilitate the establishment of the divisions, plants were initially grown in a greenhouse with set points of $21^{\circ} \mathrm{C}$ day/ $17^{\circ} \mathrm{C}$ night and natural lighting before being move to the outdoor container nursery. Plants were irrigated as needed, and provided a soluble $20 \mathrm{~N}-8.74 \mathrm{P}-16.6 \mathrm{~K}$ fertilizer (Peters 20-20-20 Fertilizer; The Scotts Co., Marysville, Ohio) at $150 \mathrm{ppm} \mathrm{N}$ once per week.

During the last week in May, just prior to being move outdoors, established divisions were transplanted into 2.6 -L plastic nursery containers (Classic 300S; Nursery Supplies, Fairless Hills, Pa.) with the same potting mixture used for establishment. Following planting, containers were top-dressed with an 8- to 9-month formulation of Sierrablen $17 \mathrm{~N}-2.6 \mathrm{P}-8.3 \mathrm{~K}$ plus micronutrients (The Scotts Co., Marietta, Ga.) at a rate of $15 \mathrm{~g}$ per plant. Trickle irrigation provided $2.7 \mathrm{~L}$ of water every other day and plants were grown under $30 \%$ shading provided by polypropy- 
lene cloth. The study was conducted outdoors from 1 June to 21 Sept. 1999, in a gravel-surfaced container nursery at the Plant Science Research Farm, in Storrs, Conn. (lat. $41^{\circ} 84^{\prime} \mathrm{N}$; long. $72^{\circ} 25^{\prime} \mathrm{W}$ ).

Shade study. Divisions for this study were also made from dormant stock plants during the first 2 weeks of April. They were established and grown under the same conditions employed for the division study, with the exception of the shade density used. Shade structures were framed with $2 \times 4$ lumber, and measured $0.75 \mathrm{~m}$ high, $1.5 \mathrm{~m}$ long, and $1.5 \mathrm{~m}$ wide. Black, woven polypropylene shade cloth was stretched over the frame and stapled into place. Shade densities provided by the cloth were verified in April using a LI-COR line quantum sensor and a model LI-189 quantum photometer (LI-COR, Lincoln, Nebr.) and were determined to be $70 \%[\approx 390$ $\mu \mathrm{mol} \cdot \mathrm{m}^{-2} \cdot \mathrm{s}^{-1}$ photosynthetically active radiation $(P A R)], 50 \%\left(\approx 650 \mu \mathrm{mol} \cdot \mathrm{m}^{-2} \cdot \mathrm{s}^{-1}\right.$ $\mathrm{PAR})$, and $30 \%\left(\approx 910 \mu \mathrm{mol} \cdot \mathrm{m}^{-2} \cdot \mathrm{s}^{-1} P A R\right)$. This study was conducted from June to Sept. in 1998 and 1999 in the facility described for the division study.

Data collection. During the third week of September of both years, plants were destructively harvested, and tiller buds, shoots, and inflorescences were counted. Shoot and root fresh and dry weights, plant height and width, leaf area, and shoot length were recorded. Root weights reflect the combined weight of both roots and crowns. Plant height was measured from the potting medium surface to the apex of the foliage, without extending the overarching leaf blades. Plant width was measured twice, at right angles to each measurement. Plant size was then estimated by multiplying height $\times$ width $1 \times$ width 2 . Leaf area was measured using a LI-COR model LI-3100 leaf area meter (LI-COR, Lincoln, Nebr.). Average shoot length per plant was determined by measuring the entire length of every shoot, including the stem and leaf blade.

Experimental design and statistical analysis. The design for the division study was a randomized complete-block design with 14 replicates. Data were analyzed through analysis of variance (ANOVA), with means separated by Fisher's LSD test at $P \leq 0.05$. The response of growth to division size and shading was determined with single degree-offreedom orthogonal polynomial contrasts. For the shade study, 14 replicates were used in 1998 and 10 in 1999. Shade treatment means were regressed onto shade density.

\section{Results and Discussion}

Division study. Most measures of final Hakonechloa plant size increased as the number of initial tiller buds per division increased (Figs. 1-2). Final plant size was greater for plants established from the two larger division sizes compared to the two smaller division sizes (Fig. 1A). This response to initial liner size was also observed for leaf area and plant weight (Figs. 1D and 2, respectively). In Fig. 1B, final shoot and tiller

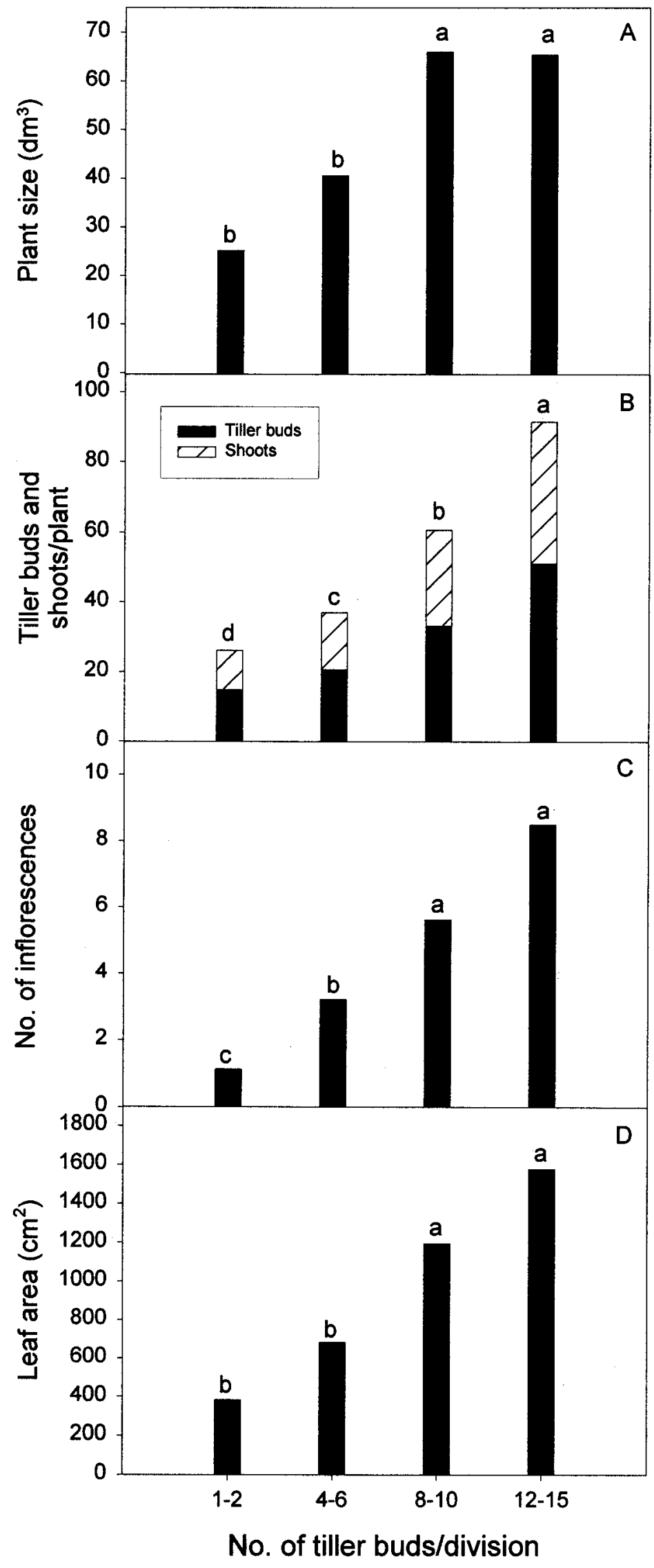

Fig. 1. Means for (A) plant size, (B) number of tiller buds and shoots, (C) number of inflorescences and (D) leaf area of Hakonechloa macra 'Aureola' after $105 \mathrm{~d}$ of growth of plants established from four different tiller sizes $(\mathrm{n}=14)$. Mean separation within each variable by Fisher's LSD test, $P \leq 0.05$. 


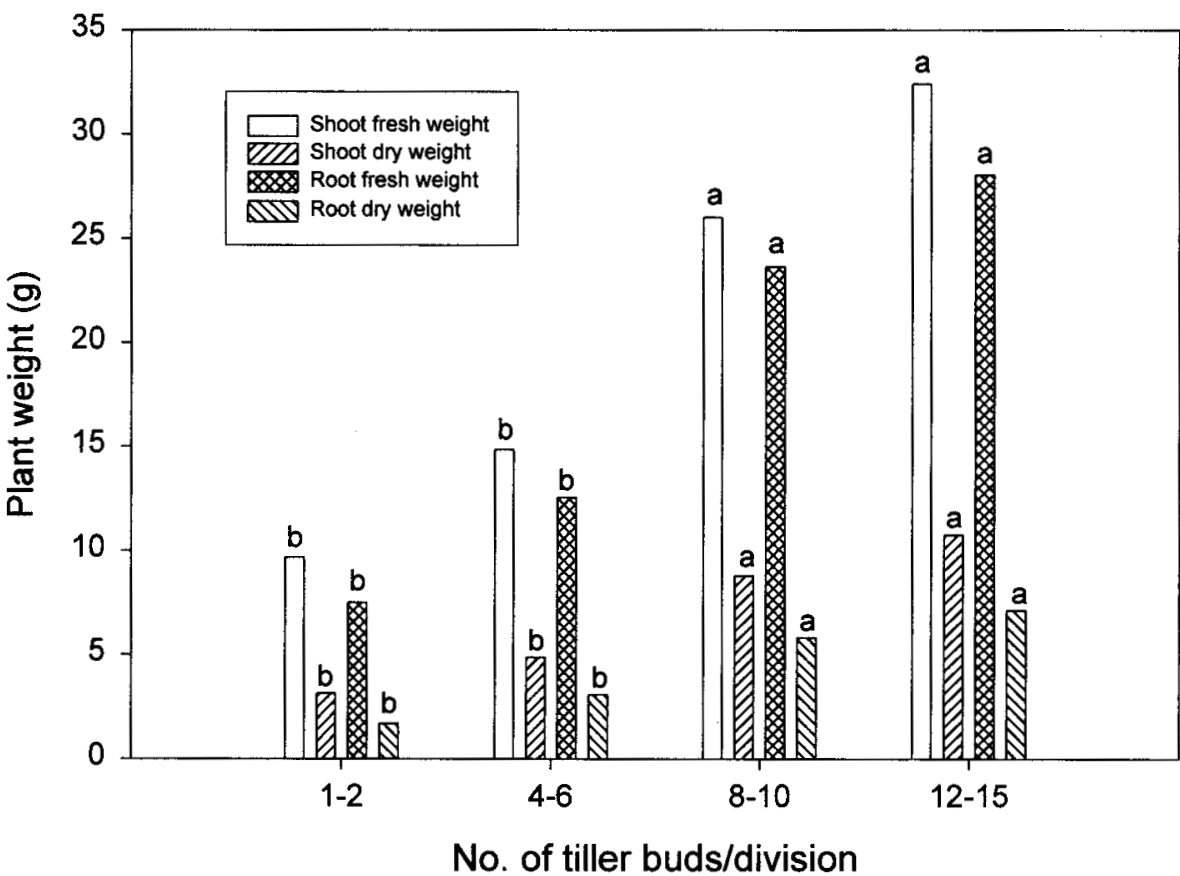

Fig. 2. Shoot and root weights after $105 \mathrm{~d}$ of growth of Hakonechloa macra 'Aureola' plants grown from four initial division sizes. Mean separation within each variable by Fisher's LSD test, $P \leq 0.05$.

Table 1. Number of tiller buds and shoots developed per initial tiller bud on Hakonechloa macra 'Aureola' plants grown from four division sizes.

\begin{tabular}{lcccc}
\hline $\begin{array}{l}\text { Initial } \\
\text { tiller buds } \\
\text { (no.) }\end{array}$ & $\begin{array}{c}\text { Final } \\
\text { tiller buds } \\
\text { (no.) }\end{array}$ & $\begin{array}{c}\text { Final tiller buds/ } \\
\text { initial tiller buds } \\
\text { (no.) }\end{array}$ & $\begin{array}{c}\text { Final } \\
\text { shoots } \\
\text { (no.) }\end{array}$ & $\begin{array}{c}\text { Final shoots/ } \\
\text { initial tiller buds } \\
\text { (no.) }\end{array}$ \\
\hline $1-2$ & $14.9 \mathrm{~d}^{y}$ & $9.9 \mathrm{a}$ & $11.3 \mathrm{~d}$ & $7.5 \mathrm{a}$ \\
$4-6$ & $20.8 \mathrm{c}$ & $4.2 \mathrm{~b}$ & $16.1 \mathrm{c}$ & $3.2 \mathrm{~b}$ \\
$8-10$ & $33.3 \mathrm{~b}$ & $3.7 \mathrm{~b}$ & $27.4 \mathrm{~b}$ & $3.0 \mathrm{~b}$ \\
$12-15$ & $51.1 \mathrm{a}$ & $3.8 \mathrm{~b}$ & $40.3 \mathrm{a}$ & $3.0 \mathrm{~b}$
\end{tabular}

${ }^{2}$ The average number of initial tiller buds in each treatment was used to calculate the final/ initial ratio.

${ }^{y}$ Mean separation within columns by Fisher's LSD test, $P \leq 0.05$.

bud counts increased with division size and were statistically different between any two division sizes. Inflorescence development increased as initial division size increased, but was nonsignificant between divisions containing 8-10 and 12-15 initial tiller buds (Fig. 1C). The only growth parameter not affected by initial division size was shoot length, which averaged $28 \mathrm{~cm}$ over all treatments (data not shown)

Based on visual observations made at the conclusion of this study, all plants from the two larger divisions sizes were considered salable. In contrast, only $30 \%$ of plants grown from divisions containing 4-6 tiller buds, and no plants from the smallest division size were marketable after one growing season. A marketable plant was defined as being comprised of $\approx 25-30$ tiller buds and 25-30 shoots, based on empirical observation. Plants grown from a division of 8-10 tiller buds contained 33 tiller buds and 27 shoots, on average, by the end of a 105-d growing season (Fig. 1B). Therefore, divisions made with no less than 8-10 tiller buds are recommended for production schedules geared toward growing marketable Hakonechloa in one growing sea- son. Hakonechloa grows relatively slowly and propagation stock is limited; therefore, economizing the use of stock material is important for meeting production demands. Use of 8-10 tiller bud divisions appears to be the most efficient use of stock material in comparison to $12-15$ tiller bud divisions.

Twice as many shoots and tiller buds developed per initial tiller bud from the smallest division size than for any other division size (Table 1). There were no differences in shoot or tiller bud production efficiencies among the three larger division sizes. This demonstrates that the smallest division size is the most efficient size for obtaining the greatest number of new tiller buds per initial tiller bud. Propagators trying to maximize the multiplication of Hakonechloa growing points should divide crowns to the smallest size possible (1-2 tiller buds). Following two propagation cycles, a grower using 2 bud divisions would be able to produce over 5000 new buds from 100 initial buds, while one using 6 bud divisions would have produced slightly over 1000 new buds.

Shade study. The magnitude of growth in 1998 was consistently higher than in 1999 for all parameters measured (Fig. 3). Limited stock material in the second year forced initial divisions to be smaller than those used in 1998. Established divisions (just prior to repotting) in 1999 had an average height of 17 $\mathrm{cm}$, a plant fresh weight of $7 \mathrm{~g}$ and two tillers. In comparison, established divisions in 1998 had an average height of $22 \mathrm{~cm}$, a weight of 24 $\mathrm{g}$ and 12 tillers.

In 1999, as shading increased, shoot fresh weight, plant size, shoot count, average shoot length, tiller bud count and leaf area increased linearly (Fig. 3). Of these measurements, only plant size and average shoot length also responded significantly to increased shading in 1998. Shading in either year did not significantly influence root weight and shoot dry weight (data not shown).

Pennisi and McConnell (2000) found that leaf length, leaf width and leaf area for variegated cultivars of Dracaena sanderiana Sander. and Liriope muscari Bailey increased as the amount of shading increased. The enlargement of leaves in response to shade results from the decrease in photosynthesis per unit leaf area that normally occurs under reduced irradiance (Corré, 1983). Stem elongation, in response to moderate reductions in irradiation, has been attributed to limited photosynthate availability and the capability of the plant to partition photosynthates into new stem growth (Kephart et al., 1992). Altered partitioning increases or maintains stem length at the expense of root growth and stem girth (Corré, 1983, Jones, 1985). Although Hakonechloa macra 'Aureola' plants grown under $70 \%$ shade grew somewhat larger than plants receiving higher light levels, they exhibited a languid, excessively drooping habit.

Apart from a favorable growth response, the shade treatments in this study also improved variegation and foliage color of Hakonechloa macra 'Aureola'. Based on empirical observation, foliar color and variegation were more vivid and had better contrast on plants grown under $50 \%$ or $70 \%$ density shade than plants grown under more light. Hakonechloa foliage grown in full sunlight was bleached and exhibited less distinct variegation. Shading has been shown to increase or maintain the chlorophyll content of foliage (Andersen et al., 1991; Brand, 1997; Newman and Follett, 1988). Elevated chlorophyll content in well-shaded Hakonechloa plants probably contributed to enhanced green and yellow color contrast in the foliage.

Manipulating division size and the density of shading can enhance production efficiency and quality of Hakonechloa grown in nursery containers. It is possible to obtain uniformly salable plants in a 3-4 month growing season using initial divisions containing as few as 8-10 tiller buds. Utilizing 1-2 tiller bud divisions doubles tiller bud production efficiency for propagation purposes. Shade density of $50 \%$ is recommended for nursery production of Hakonechloa macra 'Aureola' to enhance growth and foliage coloration. 

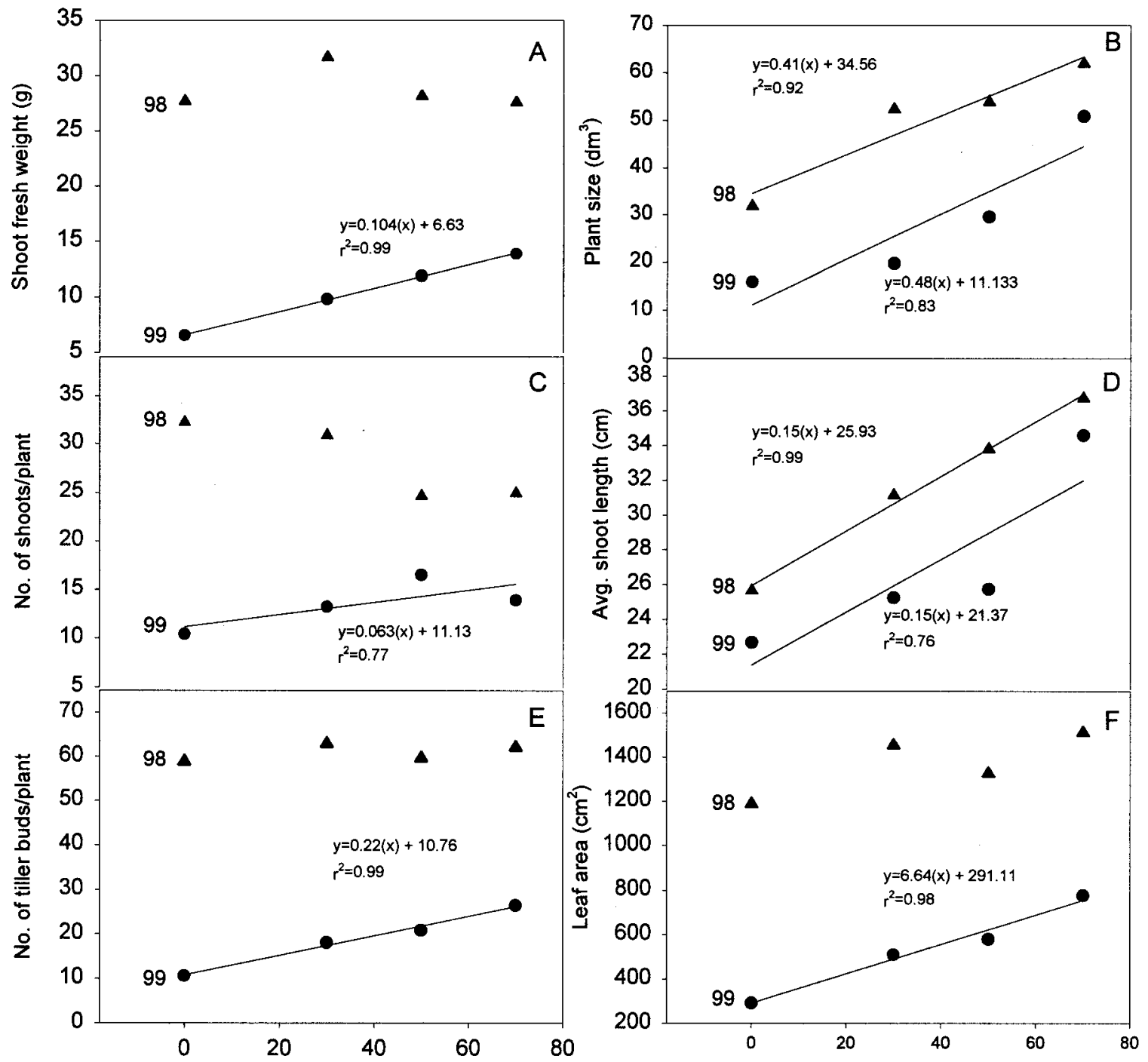

$\%$ Shade density

Fig. 3. Effect of shading on (A) shoot fresh weight, $(\mathbf{B})$ plant size, $(\mathbf{C})$ number of shoots per plant, $(\mathbf{D})$ average shoot length, $(\mathbf{E})$ number of tiller buds per plant and (F) leaf area of Hakonechloa macra 'Aureola' for $1998(\mathbf{\Delta})$ and $1999(\mathbf{O})$ after 105 d of growth. Data are significantly different where regression lines and equations are given $(P \leq 0.05)$.

\section{Literature Cited}

Andersen, P.C., J.G. Norcini, and G.W. Knox. 1991. Influence of irradiance on leaf physiology and plant growth characteristics of Rhododendron $\times$ 'Pink Ruffles'. J. Amer. Soc. Hort. Sci. 116:881-887.

Barnes, H.W. 1994. Grasses from cuttings. Proc. Intl. Plant Prop. Soc. 44:543.

Brand, M.H. 1997. Shade influences plant growth, leaf color, and chlorophyll content of Kalmia latifolia L. cultivars. HortScience 32:206-208.

Brand, M.H. 1999. Small divisions of ornamental grasses produce the best growth following direct potting. HortScience 34:1126-1128.

Cole, J.T. and J. C. Cole. 2000. Ornamental grass growth response to three shade intensities. J. Envirn. Hort. 18:18-22.
Corley, W.L. 1989. Propagation of ornamental grasses adapted to Georgia and the U.S. Southeast. Proc. Intl. Plant Prop. Soc. 39:332-337.

Corré, W.J. 1983. Growth and morphogenesis of sun and shade plants: I. The influence of light intensity. Acta Bot. Neerl. 32:49-62.

Darke, R. 1994. A century of grasses. Arnoldia $54: 2-11$.

Greenlee, J. 1992. The encyclopedia of ornamental grasses. Rodale Press. Emmaus, $\mathrm{Pa}$

Jones, C.A. 1985. C 4 grasses and cereals. Growth, development and stress response. Wiley, New York.

Kephart, K.D., D.R. Buxton and S.E. Taylor. 1992. Growth of $\mathrm{C}_{3}$ and $\mathrm{C}_{4}$ perennial grasses under reduced irradiance. Crop Sci. 32:1033-1038.

Lavis-Ham, C. 1993. The influence of temperature and container size on the growth of four orna- mental grasses. MS Thesis, Kansas State Univ., Manhattan.

Newman, S.E. and M.W. Follett. 1988. Irrigation frequency and shading influences on water relations and growth of container-grown $E u$ onymus japonica 'Aureo-marginata'. J. Environ. Hort. 6:96-100.

Pennisi, S.V. and D. B. McConnell. 2000. Made in the shade. Amer. Nurserymen 191:63-64.

Watson, L., and M.J. Dallwitz. (1992 onward). 'Grass genera of the world: Descriptions, illustrations, identification, and information retrieval; Including synonyms, morphology, anatomy, physiology, phytochemistry, cytology, classification, pathogens, world and local distribution, and references.' http:// biodiversity.uno.edu/delta/. Version: 18 Aug. 1999. 